\title{
New species of Xestoleberididae (Crustacea, Ostracoda) from Archipelago of São Pedro and São Paulo, Equatorial Atlantic
}

\author{
Nathália C. da Luz ${ }^{1} \&$ João C. Coimbra² \\ 1. Universidade Federal do Rio Grande do Sul, Programa de Pós-Graduação em Geociências/Paleontologia, Porto Alegre, RS, Brazil. (ncarvalho.luz@gmail.com) \\ 2. Universidade Federal do Rio Grande do Sul, Departamento de Paleontologia e Estratigrafia, Caixa Postal 15001, 91501-970, Porto Alegre, RS, Brazil. (joao.coimbra@ufrgs.br)
}

\begin{abstract}
Two new species of Xestoleberididae: Xestoleberis brasilinsularis sp. nov. and Xestoleberis machadoae sp. nov., both endemic to Archipelago of São Pedro and São Paulo, are described. The record of these shallow marine waters species from Brazilian oceanic islands represents an important contribution to the knowledge of the evolutionary history the species inhabit areas.
\end{abstract}

KEYWORDS. Xestoleberis, taxonomy, morphology, Atlantic Ocean.

RESUMO. Novas espécies de Xestoleberididae (Crustacea, Ostracoda) do Arquipélado de São Pedro e São Paulo, Atlântico Equatorial. Duas novas espécies de Xestoleberididae: Xestoleberis brasilinsularis sp. nov. e Xestoleberis machadoae sp. nov., ambas endêmicas do Arquipélago São Pedro e São Paulo, são descritas. O registro dessas espécies marinhas de águas rasas em ilhas oceânicas brasileiras representa uma importante contribuição para o conhecimento da história evolutiva das espécies que habitam estas áreas.

PALAVRAS-CHAVE. Xestoleberis, taxonomia, morfologia, Oceano Atlântico.

The oceanic islands are of great scientific interest, mainly their origins and their very special terrestrial and marine ecosystems. The island environments have been used as a model for many scientific fields, such as biogeography, ecology, evolution and conservation. In recent decades, the study of the Brazilian oceanic islands and their flora and fauna has grown significantly with the financial support of the governmental program known as PROARQUIPÉLAGO. This program is also responsible by the logistical support to the researches performed in the Archipelago of São Pedro and São Paulo, that is a group of very small rocky islets in the Equatorial Atlantic Ocean (CAmpos et al., 2003; CoImBra et al., 2009, 2013; Antonietto et al., 2012; Coimbra \& CARreÑo, 2012).

CormBra et al. (2013) is an important contribution to the knowledge of the ostracod fauna from the Archipelago of São Pedro and São Paulo. The authors identified and illustrated 14 species, described one new genus and species and leaving the two species of the genus Xestoleberis Sars, 1866, herein described, in open nomenclature.

Xestoleberis, a cosmopolitan marine ostracod genus, is the most specious Xestoleberididae and possesses a rich fossil record, being known since the Cretaceous (Morkhoven, 1962). This genus prefers shallow marine waters, but some of its species have been recovered from deep sea (DANiELopol et al., 1996) and marine marginal environments (Dias-Brito et al., 1988). The present paper describes and illustrates two new species of Xestoleberis, both recovered from the cove of the Archipelago of São Pedro and São Paulo, and very likely endemic to this oceanic area.

\section{MATERIAL AND METHODS}

The Archipelago of São Pedro and São Paulo $\left(00^{\circ} 55^{\prime} 10^{\prime \prime} \mathrm{N} / 29^{\circ} 20^{\prime} 33^{\prime \prime} \mathrm{W}\right)$ is the top of a submarine morphological elevation whose base is at $\sim 3,800$ m water depth. Few rocky islets compose it, being the four largest (Cabral, São Pedro, São Paulo and Belmonte) arranged in a semicircle forming a shallow cove with maximum depth of $\sim 15 \mathrm{~m}$ (Fig. 1). The Calcanhar Cape, in the State of Rio Grande do Norte, is the nearest Brazilian continental area of the Archipelago of São Pedro and São Paulo (ASPSP), whose distance is 510 nautical miles $(\sim 1,100 \mathrm{~km})$. On the other hand, the archipelago is around 985 nautical miles $(\sim 1,824 \mathrm{~km})$ from the coast of Guinea-Bissau, in Africa (Almeida, 2006).

The ASPSP and the Brazilian coast are separated by deep ocean whose depth can reach up to $4,000 \mathrm{~m}$, and in its nearest surroundings the top of some seamounts are located only $100 \mathrm{~m}$ below the surface (MORAES \& Muricy, 2007). According to Stramma \& England (1999), this archipelago is inserted into the system of equatorial currents, suffering direct influence of the South Equatorial Current, which flows superficially from east to the west, and of the South Equatorial Undercurrent, that flows in the opposite direction, at a depth ranging between 60 and $100 \mathrm{~m}$. The combined action of these two currents results in a pattern of high hydrological complexity and with great influence on the island ecosystem, causing nutrient enrichment of waters due to upwelling resulting from the interaction between ocean currents and submarine topography (CAMPOS et al., 2009).

The study material is composed by 22 samples (seven barren for Xestoleberididae) (Tab. I), hand collected in three different areas in the cove of the ASPSP by free diving at depths ranging from 2 and $11 \mathrm{~m}$ (Fig. 2). All material examined was collected by Cláudia Pinto Machado, Fernando Erthal and Sandro Monticelli Petró, with the help of the Brazilian Navy crew, during 15 days in July/August 2010. CormBra et al. (2013) present more details of field and laboratorial procedures. 


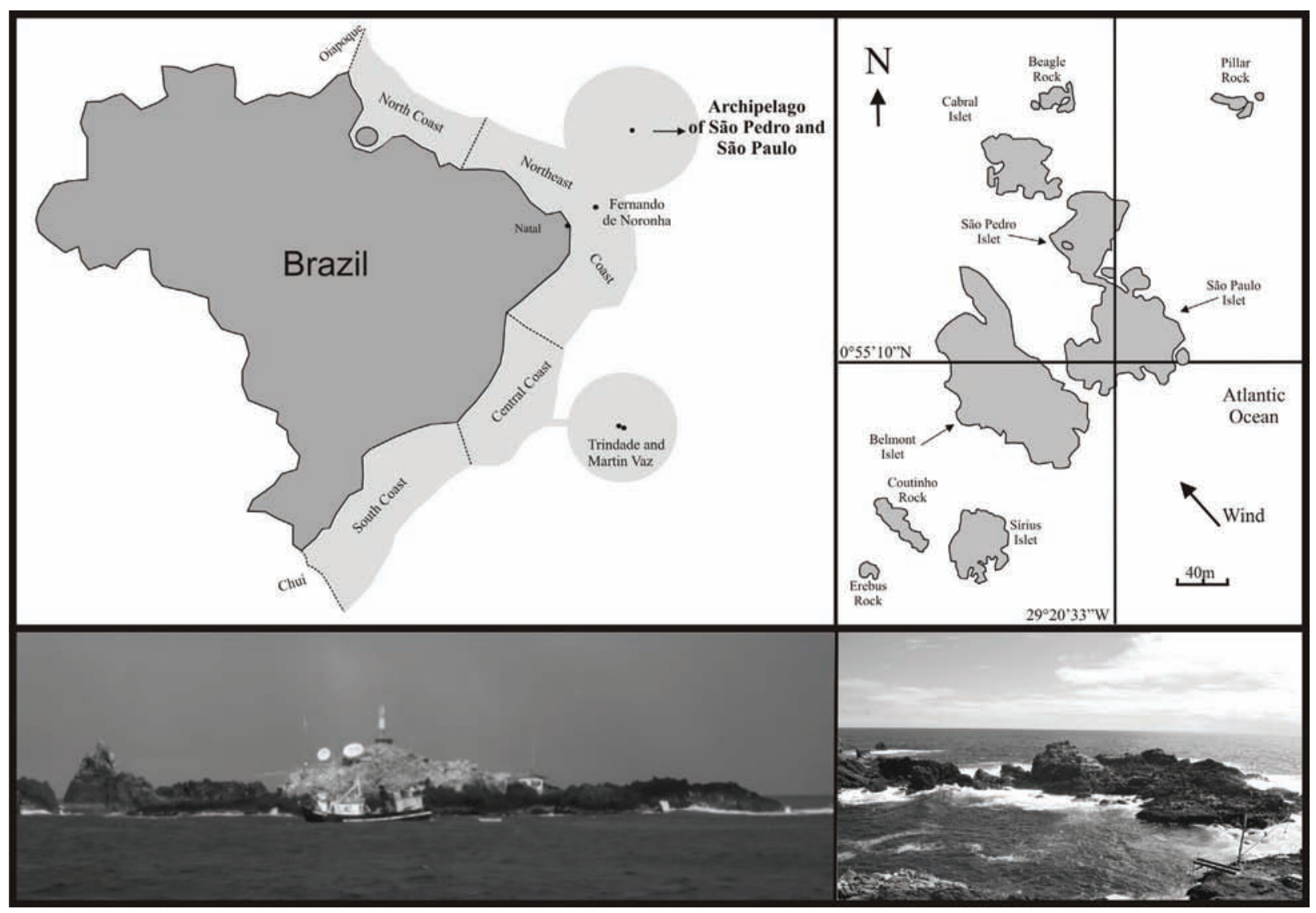

Fig. 1. Location map of Archipelago of São Pedro and São Paulo (modified from SoAres et al., 2009; MAcEdo et al., 2009).

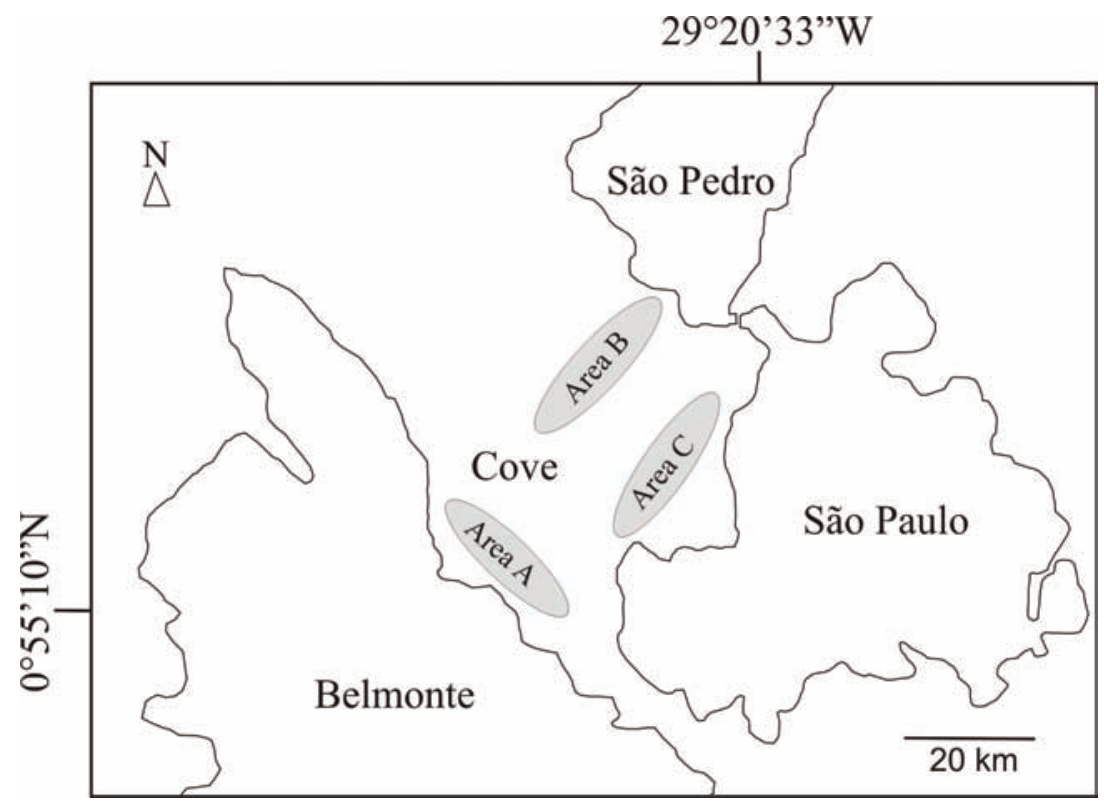

Fig. 2. Cove of the Archipelago of São Pedro and São Paulo (modified from CormBra et al., 2013).

The ostracodes herein examined are held in the collections of the 'Museu de Paleontologia', Universidade Federal do Rio Grande do Sul (UFRGS), Section of Ostracoda. The figured material is identified by the prefix MP-O. All scanning electronic microscopy (= SEM) photographs were taken at the 'Centro de Microscopia
Eletrônica' at UFRGS. Unfortunately, the LV number MP-O-2466 was broken after SEM analysis. However, only this adult specimen rendered a good photo of the central muscle scars.

Morphological abbreviations: LV, left valve; RV, right valve; c, carapace; v, valve. 
Tab. I. Number, location, substrate and depth of the 15 fertile samples for Xestoleberididae, cove of the Archipelago of São Pedro and São Paulo, Equatorial Atlantic.

\begin{tabular}{cccc}
\hline Sample number & Area of collection in the cove & $\begin{array}{c}\text { Substrate } \\
\text { (Algae/Sediment) }\end{array}$ & Depth ( m) \\
\hline M 1001-N & Area A & Algae (Caulerpa racemosa) & 2 \\
M 1002-N & Area A & Algae sp. 1 & 2 \\
M 1003-N & Area A & Sediment & 5 \\
M 1004-N & Area A & Sediment & 5 \\
M 1005-N & Area A & Sediment & 5 \\
M 1010-N & Area A & Sediment & 10 \\
M 1012-N & Area B & Sediment & 11 \\
M 1014-N & Area B & Sediment & 11 \\
M 1017-N & Area A & Algae sp. 1 & 2 \\
M 1023-N & Area C & Algae (Caulerpa racemosa) & 4 \\
M 1025-N & Area C & Algae (Caulerpa racemosa) & 4 \\
M 1030-N & Area C & Algae sp. 2 & 5 \\
M 1031-N & Area C & Algae (Caulerpa racemosa) & 5 \\
M 1032-N & Area C & Algae (Caulerpa racemosa) & 5 \\
M 1036-N & Area C & Algae sp. 2 & 5 \\
\hline
\end{tabular}

\section{Xestoleberis brasilinsularis sp. nov.}

(Figs 3-13)

Xestoleberis toni? Antonietto et al., 2012:40-41, Figs 6:9-12; Tab. 8 (non Xestoleberis toni Wouters, 2003:152, Pl. 9, Figs 1-8; Pl. 13, Figs 5a-c).

Xestoleberis sp. 1 CoImBra et. al., 2013:297, Figs 58-61; Tab. 4.

Type material. Holotype, MP-O-2474,, , RV, length: $0.42 \mathrm{~mm}$; height: $0.22 \mathrm{~mm}$. Paratypes. MP-O-2475, + , LV, length: $0.41 \mathrm{~mm}$; height: $0.22 \mathrm{~mm}$; MP-O-2476, ㅇ, carapace, width: $0.19 \mathrm{~mm}$; length: $0.40 \mathrm{~mm}$. MP-O-2477, ग, RV, length: $0.44 \mathrm{~mm}$; height: $0.21 \mathrm{~mm}$.

Etymology. From Brasil and the Latin origin, insularis $=$ of an island, because of its record being restricted to an archipelago.

Type locality. Archipelago of São Pedro and São Paulo, Equatorial Atlantic.

Occurrence. See Table II.

Diagnosis. Small-sized and relatively thin carapace. Subovate elongate to subrectangular in lateral view; ovateelongate in dorsal view. Greatest length just below midheight. Greatest height just posterior mid-length. Anterior margin obliquely rounded, with apex in the lower third.
Posterior margin subtruncated. Surface typically smooth with two types of normal pore canals: sieve-type and liptype. A very delicate flange, more developed in RV, runs along the anterior and ventral margins.

Description. A relatively thin-shelled and small-sized species of Xestoleberis. Subovate elongate to subrectangular in lateral view. In dorsal view, ovate-elongate. In ventral view, flattened. LV overlapping RV mainly anteriorly and posteroventrally. Maximum length just below mid-height. Maximum height just posterior mid-length. Maximum width posteriorly. Anterior margin obliquely rounded, with apex in the lower third. Posterior margin subtruncated. Dorsal margin moderately arched. Ventral margin sinuous near the middle, more conspicuously in RV. Surface typically smooth with two types of normal pore canals (sensu SAто \& KaмiYA, 2007): sieve-type and lip-type. A very delicate flange, more developed in RV, runs along the anterior and ventral margins. In living specimens, some very short marginal bristles overlaps the flange forming a false delicate reticulum when photographed by SEM (see Figs 3, 9). Xestoleberis-spot small and almost invisible; around it there is a milky patch. Inner lamella wide at anterior, narrow ventrally and posteriorly. Line of concrescence

Tab. II. Occurrence and abundance of living and dead Xestoleberis brasilinsularis sp. nov. recovered at the Archipelago of São Pedro and São Paulo, Equatorial Atlantic.

\begin{tabular}{ccccc}
\hline Sample number & $\begin{array}{c}\text { Substrate } \\
\text { (Algae/Sediment) }\end{array}$ & Depth $(\mathrm{m})$ & Adults & Juveniles \\
\hline M 1003-N & Sediment & 5 & $6 \mathrm{c}, 4 \mathrm{v}$ & $3 \mathrm{c}, 5 \mathrm{v}$ \\
M 1004-N & Sediment & 5 & - & $6 \mathrm{v}$ \\
M 1005-N & Sediment & 5 & $1 \mathrm{c}$ & $1 \mathrm{v}$ \\
M 1010-N & Sediment & 10 & $1 \mathrm{c}, 2 \mathrm{v}$ & $2 \mathrm{v}$ \\
M 1012-N & Sediment & 11 & $1 \mathrm{c}, 3 \mathrm{v}$ & $1 \mathrm{v}$ \\
M 1014-N & Sediment & 11 & $1 \mathrm{c}, 1 \mathrm{v}$ & $1 \mathrm{v}$ \\
M 1023-N & Algae (Caulerpa racemosa) & 4 & $1 \mathrm{v}$ & $1 \mathrm{v}$ \\
M 1025-N & Algae (Caulerpa racemosa) & 4 & $1 \mathrm{v}$ & $3 \mathrm{v}$ \\
M 1030-N & Algae sp. 2 & 5 & $1 \mathrm{v}$ & $3 \mathrm{v}$ \\
M 1031-N & Algae (Caulerpa racemosa) & 5 & - & $4 \mathrm{v}$ \\
M 1036-N & Algae sp. 2 & 5 & & $1 \mathrm{v}$ \\
\hline
\end{tabular}




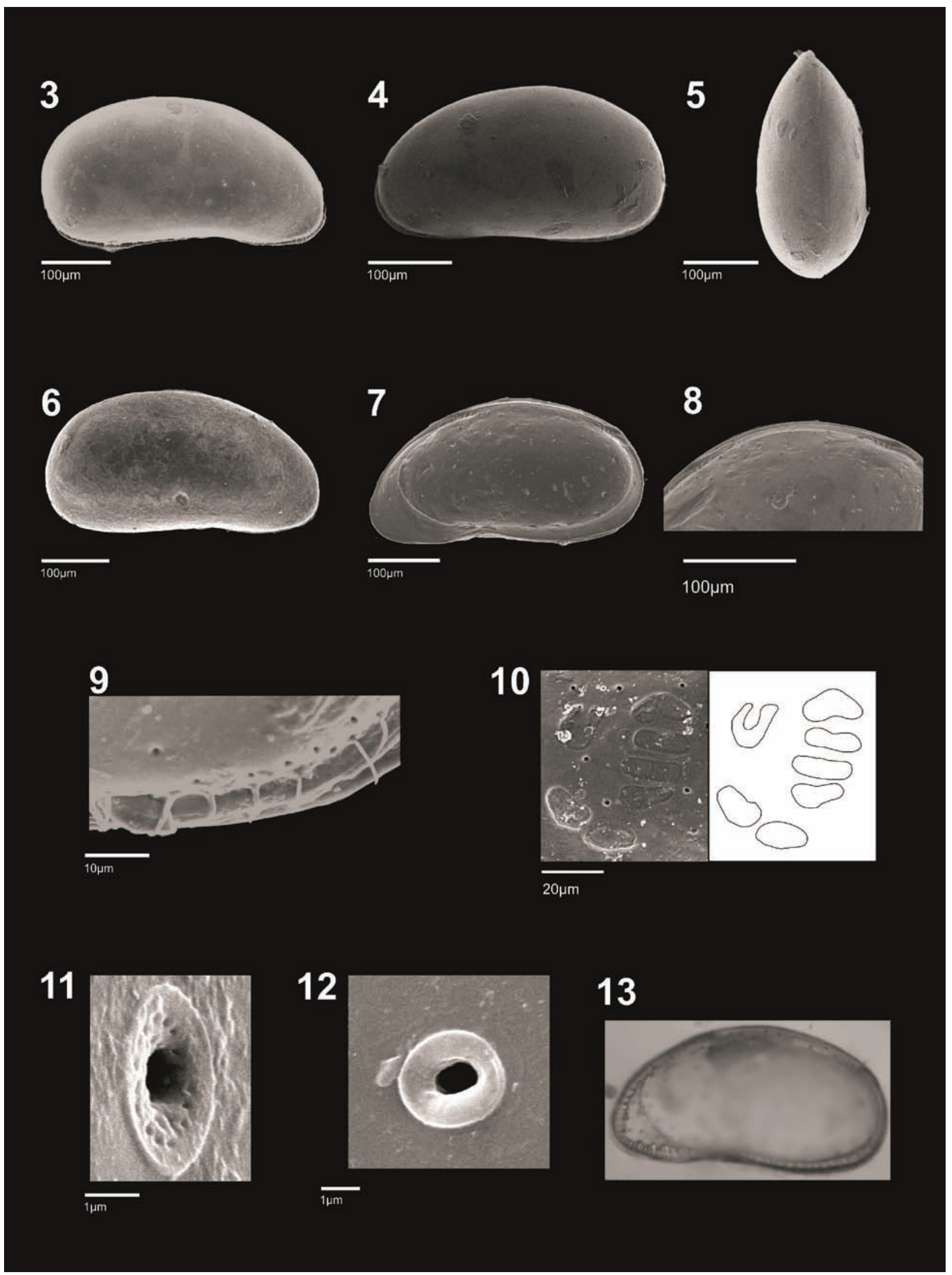

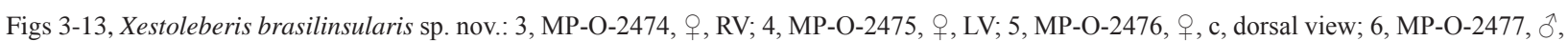

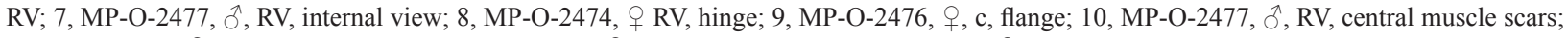
11, MP-O-2474, o, c, sieve-type pore; 12, MP-O-2476, + , c, lip-type pore; 13, MP-O-2474,, , RV, internal view, not in scale. 
and inner lamella widely separated anteriorly, forming a large vestibulum. Posterior vestibulum very small, visible only in large magnification. Selvage subperipheral in both valves, bending outwards in the oral region. Marginal pore canals numerous and short, mostly simple and straight, as typical for the genus. Hinge hemimerodont, with welldeveloped crenulate terminal teeth in RV; median element smooth. Central muscle scars constituted by four adductors vertically aligned and a frontal U-shaped. Two mandibular scars below in front. Sexual dimorphism: females more inflated posteriorly, somewhat more height and with a more marked oral concavity. Males more rounded posteriorly.

Remarks. Xestoleberis brasilinsularis sp. nov. was identified by ANTONIETTO et al. (2012) as Xestoleberis toni? Wouters, 2003. However, as already briefly discussed by CoImBra et al. (2013), these two taxa are not conspecific. In fact, they have not only different outlines, but also different central muscle scars pattern and Xestoleberis spot, that is larger in the species described by Wouters (2003) for Cape Verde Islands. The new species does not fit well in any Xestoleberis morphological group proposed by Bonaduce \& Danielopol (1988) neither by SATo \& KAMIYA (2007).

\section{Xestoleberis machadoae sp. nov.}

(Figs 14-24)

Xestoleberis sp. 1 Antonietto et al., 2012:40-41, Figs. 6:13-20; Tab. 9. Xestoleberis sp. 2 CoimBra et. al., 2013:297, Fig. 62-66; Tab. 4.

Type material. Holotype, MP-O-2478, 9 , RV, length: $0.34 \mathrm{~mm}$; height: $0.19 \mathrm{~mm}$. Paratypes. MP-O-2466, $\mathrm{O}^{\lambda}$, RV, length: $0,28 \mathrm{~mm}$; height: $0,13 \mathrm{~mm}$; MP-O-2479, क, LV, length: $0.33 \mathrm{~mm}$; height: $0.16 \mathrm{~mm}$; MP-O-2480, o, carapace, width: $0.21 \mathrm{~mm}$; length: $0.32 \mathrm{~mm}$; MP-O-2481, ${ }^{1}$, RV, length: $0.33 \mathrm{~mm}$; height: $0.16 \mathrm{~mm}$; MP-O-2482, ô, LV, length: $0.34 \mathrm{~mm}$; height: $0.16 \mathrm{~mm}$; MP-O-2483, o, carapace, width: $0.19 \mathrm{~mm}$; length: $0.33 \mathrm{~mm}$.
Etymology. This species was named in honor of Cláudia Pinto Machado (Universidade de Caxias do Sul), a friend of the authors, in recognition of her contribution to the study of Recent Brazilian shallow water marine ostracodes, and for her tireless willingness to collect ostracodes in inhospitable Brazilian oceanic islands.

Type locality. Archipelago of São Pedro and São Paulo, Equatorial Atlantic.

Occurrence. See Table III.

Diagnosis. Carapace very small and relatively thin. Subrectangular elongate in lateral view; in dorsal view, oval in females and subpiriform in males. In ventral view, strongly flattened. Anterior margin obliquely rounded, projected ventrally, with an adjacent small sunken area. Posterior margin almost evenly rounded in RV, more narrowly rounded in LV. Surface predominantly smooth, with three different normal pore canals: sieve-type, simpletype and lip-type. In SEM, there are one very delicate anteroventral submarginal rib and two minor ribs behind it.

Description. A very small and relatively thinshelled species of Xestoleberis. Subrectangular elongate in lateral view. In dorsal view, strongly inflated and ovate. In ventral view, strongly flattened. LV overlapping RV mainly anteriorly and posterodorsally. Maximum length almost ventrally. Maximum height medially. Maximum width near the middle. Anterior margin obliquely rounded, projected ventrally, with a depressed region adjacent to it forming a well-defined small sunken area. Posterior margin almost evenly rounded in RV, more narrowly rounded in LV. Dorsal margin moderately convex. Ventral margin almost straight, hidden by a lateral inflation more developed in LV. Surface predominantly smooth, with three patterns of normal pore canals (sensu SAто \& KaмiYa, 2007): sieve-type, simpletype and lip-type. In SEM, there are one very delicate anteroventral submarginal rib and two minor ribs behind it. Xestoleberis-spot small and almost invisible. A large vestibulum is present anteriorly. Selvage subperipheral in both valves, bending outwards in the oral region. Marginal

Tab. III. Occurrence and abundance of living and dead Xestoleberis machadoae sp. nov. recovered at the Archipelago of São Pedro and São Paulo, Equatorial Atlantic.

\begin{tabular}{ccccc}
\hline Sample number & $\begin{array}{c}\text { Substrate } \\
\text { (Algae/Sediment) }\end{array}$ & Depth $(\sim \mathrm{m})$ & Adults & Juveniles \\
\hline M 1001-N & Algae (Caulerpa racemosa) & 2 & - & $1 \mathrm{c}$ \\
M 1002-N & Algae sp. 1 & 2 & $1 \mathrm{c}$ & $1 \mathrm{c}$ \\
M 1003-N & Sediment & 5 & $15 \mathrm{c}, 32 \mathrm{v}$ & $3 \mathrm{c}, 15 \mathrm{v}$ \\
M 1004-N & Sediment & 5 & $20 \mathrm{c}, 7 \mathrm{v}$ & $2 \mathrm{c}, 1 \mathrm{v}$ \\
M 1005-N & Sediment & 5 & $17 \mathrm{c}, 11 \mathrm{v}$ & $3 \mathrm{v}$ \\
M 1010-N & Sediment & 10 & $1 \mathrm{c}, 1 \mathrm{v}$ & $1 \mathrm{v}$ \\
M 1012-N & Sediment & 11 & $2 \mathrm{c}$ & $7 \mathrm{c}$ \\
M 1014-N & Sediment & 11 & - & - \\
M 1017-N & Algae sp. 1 & 2 & - & $3 \mathrm{v}$ \\
M 1023-N & Algae (Caulerpa racemosa) & 4 & $1 \mathrm{v}$ & $1 \mathrm{c}, 1 \mathrm{v}$ \\
M 1025-N & Algae (Caulerpa racemosa) & 4 & $2 \mathrm{v}$ & $1 \mathrm{c}, 1 \mathrm{v}$ \\
M 1030-N & Algae sp.2 & 5 & $1 \mathrm{v}$ & - \\
M 1032-N & Algae (Caulerpa racemosa) & 5 & -
\end{tabular}




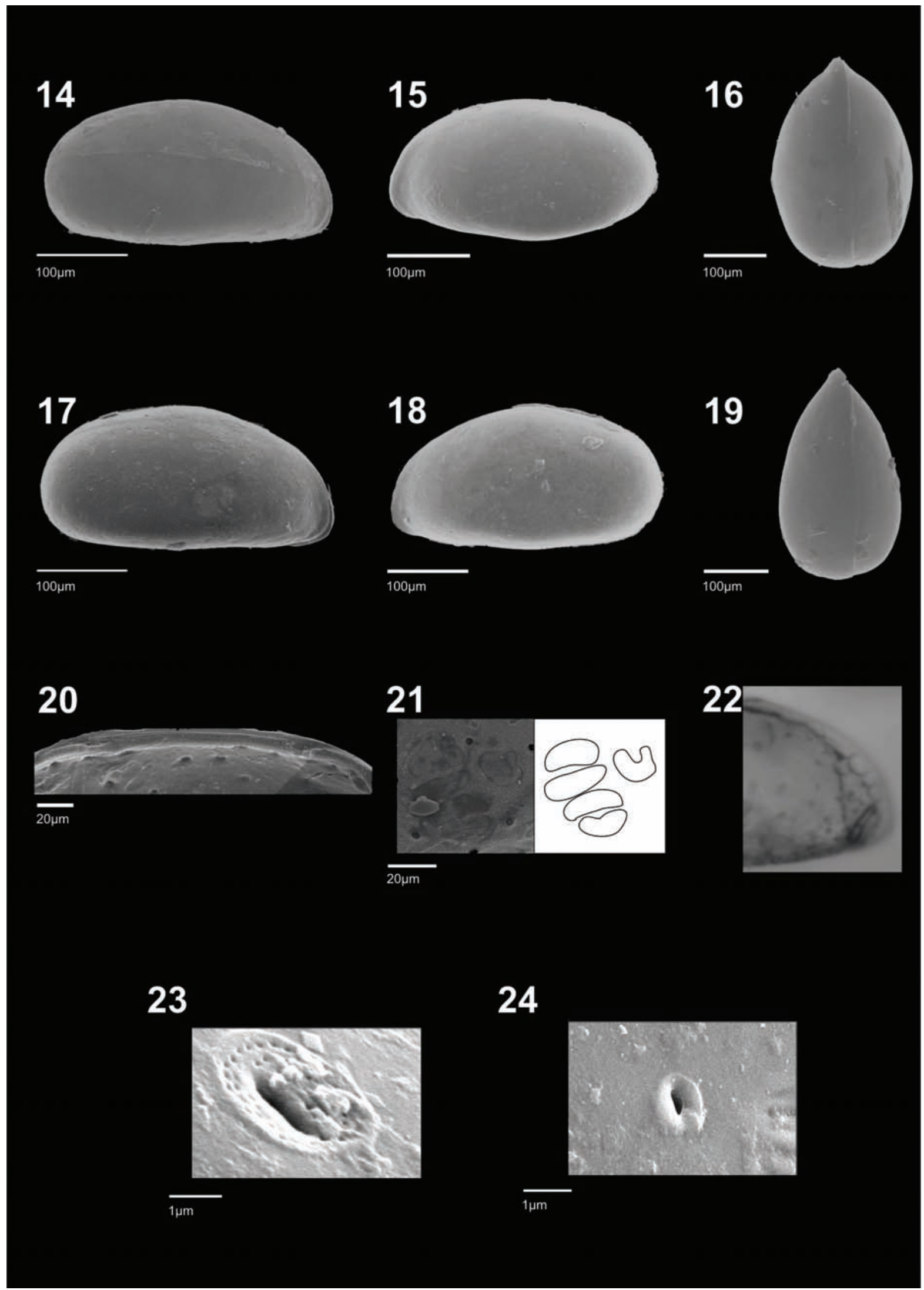

Figs 14-24, Xestoleberis machadoae sp. nov.: 14, MP-O-2478, ․ RV; 15, MP-O-2479, ㅇ, LV; 16, MP-O-2480, ๆ, c, dorsal view; 17, MP-O-2481,

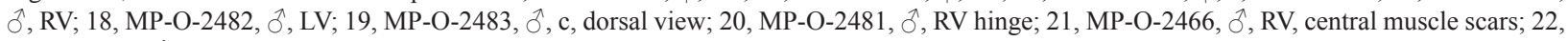

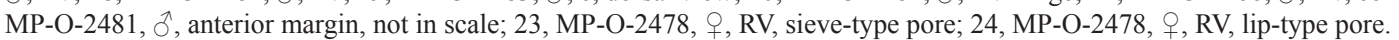


pore canals not numerous, simple and straight. Hinge hemimerodont, with delicately crenulate terminal teeth in RV; median element smooth. Central muscle scars constituted by four adductors vertically aligned and a frontal U-shaped. Mandibular scars not visible. Sexual dimorphism present. Males with a more arched dorsal margin and less developed lateral inflation in LV. In dorsal view, subpiriform. Maximum width posteriorly.

Remarks. Xestoleberis machadoae sp. nov. has less than $0.4 \mathrm{~mm}$ in length, exhibits elongate and dorsally gently convex valves in lateral view, hinge hemimerodont with slightly crenulate terminal teeth in RV and smooth hinge-bar in LV, and Xestoleberis-spot poor-developed, features typical of the Xestoleberis arcturi Triebel group of Bonaduce \& Danielopol (1988). Conversely, this new species does not fit well in any group proposed by SATO \& KamiYa (2007) for Japanese species.

\section{DISCUSSION}

The study of Recent and Quaternary ostracodes of the family Xestoleberididae in Brazil showed that the species of the genus Xestoleberis already identified are mainly under open nomenclature. CoImBRA et al. (1992), analyzing the relationship of ostracodes, biofacies of foraminifers and lithofacies in the coralline Bay of Tamandaré (NE Brazil), identified Xestoleberis spp. only in the carbonate lithofacies. CoImBra et al. (1999) recorded Xestoleberis sp. 1 along the entire equatorial shelf, while Xestoleberis sp. 2 was identified only in the most western portion of that region. MACHADO et al. (2005), studying very shallow water ostracodes off Cabo Frio town $\left(\sim 22^{\circ} \mathrm{S}\right)$, in the state of Rio de Janeiro, identified Xestoleberis umbonata Whatley et al., 1998, one of the dominant ostracod species in their material. BERGUE \& CoImBra (2008), in a study of littoral benthic meiofauna of the State of São Paulo, recorded only five specimens of a species of this genus that remained in open nomenclature. CoImBra et al. (2009) and CoIMBRA \& CARREÑo (2012), in a preliminary study of ostracodes from the Trindade Island $\left(20^{\circ} 30^{\prime} \mathrm{S}, 29^{\circ} 18^{\prime} \mathrm{W}\right)$ and Rocas Atoll $\left(03^{\circ} 52^{\prime} \mathrm{S}, 33^{\circ} 09^{\prime} \mathrm{W}\right)$, two oceanic Brazilian islands, recorded Xestoleberis sp. in Trindade and Xestoleberis spp. in Rocas. CormBra et al. (2013), as already briefly presented in the introduction of this paper, also discussed preliminarily the two taxa herein formally described. In that paper, the authors outlined a first comparison among the ostracod fauna of three Brazilian oceanic islands (ASPSP, Trindade and Rocas) and discussed the dispersal and potential of colonization of isolated oceanic islands by benthic ostracodes. Finally, the first author, examining 377 samples recovered from the north and northeastern Brazilian shelf, found four unidentified species of Xestoleberis that will be studied in an ongoing project.

A comparison of all species of Xestoleberis above discussed with the two new species of this genus described for the ASPSP, revealed no similarity among $X$. brasilinsularis sp. nov., X. machadoae sp. nov. and any of those taxa.

Acknowledgments. The authors acknowledge Cláudia P. Machado, Fernando Erthal and Sandro M. Petró for their help in the fieldwork activities. The "Comissão Interministerial para os Recursos do Mar-SECIRM" and the "Universidade Federal do Rio Grande do Norte - UFRN" are thanked for logistical assistance. Two anonymous reviewers contributed with thoughtful comments on the manuscript. The authors are also grateful to the "Conselho Nacional de Desenvolvimento Científico e Tecnológico - CNPq" for financial support (proc. 404301/2012-6 and 304453/2013-7). Eugen K. Kempf suggested the specific epithet of the new species Xestoleberis brasilinsularis.

\section{REFERENCES}

AlmeidA, F. F. M. 2006. Ilhas oceânicas brasileiras e suas relações com a tectônica atlântica. Terrae Didatica 2(1):3-18.

Antonietto, L. S.; Machado, C. P.; Do Carmo, D. A. \& Rosa, J. W. C. 2012. Recent Ostracoda (Arthropoda, Crustacea) from São PedroSão Paulo Archipelago, Brazil: a preliminary approach. Zootaxa, 3335:29-53.

Bergue, C. T. \& Coimbra, J. C. 2008. Late Pleistocene and Holocene bathyal ostracodes from the Santos Basin, southeastern Brazil. Palaeontographica, Abteilung A, Palaozoologie, Stratigraphie 285:101-144.

Bonaduce, G. \& Danielopol, D. 1988. To see and not to be seen: The evolutionary problems of the Ostracoda Xestoleberididae. In: HanaI, T.; IKEYA, N. \& ISHIZAKI, K. eds. Evolutionary biology of Ostracoda. Amsterdam, Elsevier, p. 375-398.

Campos, T. F. C.; Petta, R. A.; Theye, T.; Sichel, S. E.; Simões, L. S. A.; Srivastava, N. K.; Motoki, A. A.; Virgens Neto, J. \& Andrade, F. G. G. 2009. Posição ímpar do Arquipélago São Pedro e São Paulo na diversidade geológica da Terra. In: Viana, D. L.; Hazın, F. H. V. \& Souza, M. A. C. orgs. O Arquipélago de São Pedro e São Paulo: 10 anos de Estação Científica. Brasília, SECIRM, p. 54-63.

Campos, T. F. C.; Virgens Neto, J.; Amorim, V. A.; Hartmann, L. A. \& Petta, R. A. 2003. Modificações metassomáticas das rochas milonitizadas do complexo ultramáfico do Arquipélago São Pedro e São Paulo, Atlântico Equatorial. Geochimica Brasiliensis 17(2):081090 .

Coimbra, J. C.; Bottezini, S. R. \& Machado, C. P. 2013. Ostracoda (Crustacea) from the Archipelago of São Pedro and São Paulo, Equatorial Atlantic, with emphasis on a new Hemicytheridae genus. Iheringia, Série Zoologia 103(3):289-301.

Coimbra, J. C. \& Carreño, A. L. 2012. Richness and palaeozoogeographical significance of the benthic Ostracoda (Crustacea) from the oceanic Island of Trindade and Rocas Atoll, Brazil. Revista Brasileira de Paleontologia 15:189-202.

Coimbra, J. C.; Ghillardi, V.; Casetta, G. M. \& Bergue, C. T. 2009. Ostracodes (Crustacea) da Ilha da Trindade e do Atol das Rocas, Brasil. In: Mohr, L. V.; Castro, J. W.; Costa, P. M. S. \& Alves, R. V. orgs. Ilhas Oceânicas Brasileiras: da Pesquisa ao Manejo. Brasília, Ministério do Meio Ambiente, v. 2, p. 125-141.

Coimbra, J. C.; Pinto, I. D.; Würdig, N. L. \& Carmo, D. A. 1999. Zoogeography of Holocene Podocopina (Ostracoda) from the Brazilian Equatorial shelf. Marine Micropaleontology 37(3/4):365379.

Coimbra, J. C.; Ramos, M. I. F. \& Sanguinetti, Y. T. 1992. Sub-recent Ostracodes of the Tamandaré Bay, Northeastern Brazil - a Preliminary Report on Biofacies. Pesquisas 19(1):94-105.

Danielopol, D.; Baltanás, A. \& Bonaduce, G. 1996. The Darkness Syndrome in Sub-surface-shallow and Deep Sea Dwelling Ostracoda (Crustacea). Biosystematics and Ecology Series 11:123-143.

Dias-Brito, D.; Moura, J. A. \& Würdig, N. L. 1988. Relationships between ecological models based on ostracods and foraminifers from Sepetiba Bay (Rio de Janeiro-Brazil). In: HANAI, T.; IKEYA, N. \& IsHIZAKI, K. eds. Evolutionary biology of Ostracoda. Amsterdam, Elsevier, p. 467-484. 
Macedo, S. J.; Montes, M. J. F. \& Costa, K. M. P. 2009. Hidrologia. In: Viana, D. L.; Hazin, F. H. V. \& SouzA, M. A. C. orgs. O Arquipélago de São Pedro e São Paulo: 10 anos de Estação Científica. Brasília, SECIRM, p. 100-105.

Machado, C. P.; Coimbra, J. C. \& CArreño, A. L. 2005. The ecological and zoogeographical significance of the sub-Recent Ostracoda off Cabo Frio, Rio de Janeiro State, Brazil. Marine Micropaleontology 55(3/4):235-253

Moraes, F. \& Muricy, G. 2007. A new species of Stoeba (Demospongiae: Astrophorida) from oceanic islands off northeastern Brazil. Journal of the Marine Biological Association of the United Kingdom 87:1387-1393.

Morkhoven, F. P. C. M. 1962. Post-Palaeozoic Ostracoda: their morphology, taxonomy, and economic use. Vol. II. Amsterdam, Elsevier. 478p.
SAto, T. \& KamiYa, T. 2007. Taxonomy and geographical distribution of recent Xestoleberis species (Cytheroidea, Ostracoda, Crustacea) from Japan. Paleontological Research 11(2):183-227.

Soares, J.; Oliveira, A. P., Skielka, U. T. \& Servain, J. 2009. O ar. In: VianA, D. L.; Hazin, F. H. V. \& SouzA, M. A. C. orgs. O Arquipélago de São Pedro e São Paulo: 10 anos de Estação Científica. Brasília, SECIRM, p. 38-44.

Stramma, L. \& England, M. 1999. On the water masses and mean circulation of the South Atlantic Ocean. Journal of Geophysical Research 104:20863-20883.

Wouters, K. 2003. Taxonomy and zoogeography of intertidal Ostracoda (Crustacea) from the Cape Verde Islands (Atlantic Ocean). Bulletin de l'Institut Royal des Sciences Naturelles de Belgique, Biologie 73:137-159. 